\title{
PRINCIPLE 10, THE AARHUS CONVENTION AND STATUS OF PUBLIC PARTICIPATION IN ENVIRONMENTAL MATTERS IN THE MALAYSIAN LAWS WITH SPECIAL REFERENCE TO EIAs
}

\author{
Abdul Haseeb Ansari*
}

\begin{abstract}
Like many countries that are really keen to strike a meaningful balance between environment and development and for the wish to employ environment impact assessment (EIA) as a necessary tool, Malaysia has made it mandatory with respect to nineteen activities that are likely to leave deleterious effects on the environment. The law provides for adhering to the widely accepted procedure, including people's participation, especially of those who might be affected by proposed development projects or any other activity to which an EIA is a necessary requirement. In spite of the fact that the law enshrines the cardinal points of Principle 10 of the Rio Declaration and the Aarhus Convention and is comparable with similar laws in some developed countries, the conditions of the components of the environment are not improving. Some say it is because of the flaccidness on the part of those who are
\end{abstract}

Professor, Ahmad Ibrahim Kulliyyah of Laws, International Islamic University Malaysia. 
responsible to approve EIAs; some others blame irresponsible developers and factory owners and poor enforcement of the environmental law as a whole, including poor public participation. In fact, both are responsible for the deleterious conditions of the environment and its various unfettered harmful processes. The paper limits its scope to critical appraisal of the law pertaining to EIA, its enforcement in the country with special emphasis on public participation, and offers constructive and functional suggestions pertaining to public participation so that it is properly enforced and serves the desired objective of sustainable development and protection of the environment.

\section{INTRODUCTION}

Although environment impact assessment (hereinafter referred to as EIA/EIAs) is not uniformly defined, ${ }^{1}$ it is very well understood as a

$1 \quad$ The National Environmental Policy Act 1969 (USA), which first emphasised the doing of EIAs with respect to certain activities, defines it as: "A systematic interdisciplinary approach which will ensure the integrated use of the natural and social sciences and the environmental design ...in planning and in the decision-making which may have an impact on the environment.” See U.S.C. 4320-4361, section 102(a). Munn defines it as: "A process for identifying the likely consequences for the biological, geological and physical environment, as well as human health and welfare of implementing particular activities; and for conveying this information to those responsible for sanctioning the proposal at a stage when it can materially affect their decision." See R.E. Munn, Environmental Impact Assessment: Principles and Procedures (New York: John Wiley, 1979), 10. The EIA Handbook, issued by the Department of Environment of Malaysia, defines it as: “.... a study to identify, predict, evaluate and communicate information about the impacts on the environment of a proposed project and to detail out the mitigating measures prior to project approval and implementation." See Department of Environment, A Handbook of Environmental Impact Assessment Guidelines, 2000, 48. According to 
process of identifying the likely deleterious consequences of certain activities, especially developmental and industrial activities, on the environment and its processes. It is a prudent tool to create a meaningful balance between environment and development, which is imperatively demanded by the essential principles arising from 'Agenda 21, commonly known as sustainable development,' ${ }^{2}$ the 'Precautionary Principle,' ${ }^{3}$ 'Principle 10 of the Rio Declaration' and the 'inter-generational equity' principle. In view of this, Principle 17 of the Rio Declaration acknowledges it: “... as a national instrument...undertaken for proposed activities that are likely to have a significant adverse impact on the environment and are subject to a decision of a competent national authority.” Since EIAs are prudent and efficient preventive tools for protecting the environment from being degraded due to developmental activites that are necessary for economic development, most of the countries have formally recognised it and have suitably enacted law to enforce it. ${ }^{4}$ The scope of

Harvey, it is the process of identification of the potential environmental impact (including biological, geophysical, socio-economic and cultural) of proposed actions, policies, programs and projects so that the information can be communicated to decision makers before they decide to approve the proposed development activities. See N. Harvey, Environmental Impact Assessment: Procedure, Practice and Prospects in Australia (Melbourne: Oxford University Press, 1998), 2.

2 By virtue of this principle, which was first defined by the Brundtland Commission, enjoyment of natural resources will not be at the cost of coming generations. See Abdul Haseeb Ansari, "Toward Sustainable Land Use Planning” paper presented at II IUCN Colloquium, 4-7 October 2004, Nairobi, Kenya.

$3 \quad$ See Abdul Haseeb Ansari, "Meaning, Scope and Implementation of Precautionary Principle: A Critical Appraisal," Indian Journal of International Law, vol. 43, 2003, 625.

$4 \quad$ Almost all countries, developed and developing, have laws for conducting EIAs. Although these laws follow the basic idea of protecting the environment, their modalities differ according to their suitability and the political will of states. Developed countries and their people prefer tougher preventive laws because they can afford to have them; on the contrary, developing countries, which have to go a long way and invariably suffer from lack of financial resources, scarcity of sophisticated technologies and fewer number of trained personnel, would not like to follow laws of that standard or would fail to enforce such laws. They, thus, prefer to remain at the lower threshold of EIA laws. 
EIAs have further been widened by associating it with social impact assessments (herein after referred to as SIA/SIAs), where proposed activities might leave adverse socio-economic or cultural impact, especially where due to such activities, a sizable number of people will have to be displaced or will otherwise be affected presently or in future. In such situations, it is said that both EIAs and SIAs must go hand-inhand. ${ }^{5}$ In its widest possible connotation, environmental impact can be understood as the process of assessing or estimating, in advance, adverse environmental and social consequences that are likely to follow from specific policy actions or development projects, particularly in the context of appropriate national, state or provincial environmental legislation and development activities carried on under it. 'Social impacts' include all social and cultural consequences immediate or in the past to human populations of any public or private actions that alter the ways, in which people live, work, play, relate to one another, organize to meet their needs, and generally cope as members of the society. Cultural impacts involve changes to the norms, values and beliefs of individuals that guide and rationalise the cognition of themselves and their societies. ${ }^{6}$ They, thus, have potential to contribute to planning processes and developmental activities in a positive way. In addition to enforcing some kind of EIA mechanism, ${ }^{7}$ it is also recognised by some international environmental conventions ${ }^{8}$ and other international legal instruments of a 'soft law'

$5 \quad$ The best example of this is construction of a dam, which might displace a large number of people, and in case of breach it might cause widespread damage to people and their beneficiaries. Another example is building infrastructures.

$6 \quad$ See Rabel J. Burdge and Frank Vanclay, Social Impact Assessment: A Contribution to State of the Art Series (New York: John Pub., 1996), 59-77.

$7 \quad$ It is mandatory with respect to certain activities and recommendatory with respect to certain other activities.

$8 \quad$ Notable among them are: the Convention on Environmental Impact Assessment in a Transboundary Context, 1991 [Article 1], 30 ILM 802; the United Nations Convention on Biological Diversity, 1992 [(Art. 14 (1) (a)], 31 ILM 818; the United Nations Framework Convention on Climate Change, 1992 [Article 4 (1) (f)], 31 ILM 849; the United Nations Convention on Law of the Sea, 1982 [Article 206], 1295 UNTS, 211; the Convention on Access to Information, Public Participation in DecisionMaking and Access to Justice in Environmental Matters, 1998, UNECE 
nature, as a necessary preventive measure to be adopted by member states.

An EIA process generally contains the following imperatives: identification and prediction of significant effect of the proposed activity on the environment; evaluation of various alternatives that are available for the proposed activity; suggestions about mitigating measures to alleviate the deleterious unacceptable impacts on the environment; selection of the best among the alternatives; and presenting these in a form of a report before the appropriate authority for its approval and its ultimate approval or rejection. As a matter of general practise, some activities, which might have greater degree of chances to leave deleterious effect on the environment, have been subjected to a mandatory EIA, and some other activates, which may or may not have adverse effect on it, are left to have it on as optional basis. It is a generally accepted procedural practice that the proponent of the activity gets an EIA prepared by experts that are generally registered with or approved by the Department of Environment (hereinafter referred to as DOE) or any other appropriate body and submits it to the designate authority. The authority scrutinises the EIA report through certain experts and issues appropriate orders. The authority may approve the preliminary report with or without any conditions, or may reject it. Rejection does not amount to disapproval of the proposed project. In this case, the proponent is not debarred from submitting another report. In case certain additional information is warranted by the authority, the proponent is required to modify the report accordingly and re-submit it. After the input of suggested modification in the report, the final report takes the shape. It is approved with or without certain conditions to be followed throughout the implementation of the project. With respect to certain activities, which might seriously affect the environment, detailed EIA reports are prepared by a group of experts, and the reports are intensively scrutinized by another group of experts at DOE. In some countries, including India, based on

Website; the United Nations Convention to Combat Desertification in Those Countries Experiencing Serious Drought and/or Desertification, Particularly in Africa, 1994 [Article 9], <http://sedac.ciesin.org/pidb/ texts/un.desertification.final.resolution.1994.html>; and the Madrid Protocol under the Convention for the Regulation of Antarctic Mineral Resources Activities, 1988, ,http://www.polarlaw.org/Treaty.htm> 
the proposed project, a prototype replica of the project is made, and it undergoes an intensive kind of testing for two-to-three months. The project is allowed only when experts at the Department of Environment and the Testing Department approve it.

On going projects are subject to follow up EIAs. Thus, a project that has an approved EIA can be stopped if a subsequent EIA reveals that allowing the project to go further will leave irreparable deleterious effects on the environment. In the whole process, the substantive law contained in the specific environmental legislations and legislations on town and country planning and supported with suitable subsidiary laws, made there under - to facilitate making EIAs, to ensuring public participation and to get them through the approving authorities - play the central role. Some countries have incorporated the EIA law in their town and country-planning regime. ${ }^{9}$ So as to provide guidance in preparing EIA reports, suitable guidelines have also been made. ${ }^{10}$

In the whole process, public participation is generally considered as a relationship between the public and the decision-maker that ranges from provision of information sharing and reaching consensus on the form and modality of the proposed development planning or developmental project through various forms of interactive consultations. This is because for various reasons, direct public control in the decision-making on all kinds of EIAs, is crucial. Notable among them are: infusing into them the basic idea of environmental democracy as it brings all stakeholders, the proponent, the government authorities and the public, together; linking environmental rights and human rights; and ensuring environmental justice. ${ }^{11}$ It also provides opportunity to a large group of people to think about the possible adverse impact of proposed projects on the environment and the society, which will invariably bring in a sense of confidence about

$9 \quad$ See A. Galpin, Environment Impact Assessment (Cambridge: Cambridge University Press, 1995) Chapters 8 and 9.

$10 \quad$ Malaysia has the three sets of laws: Environmental Quality Act, 1974; Environmental Quality (Prescribed Activities) (Environment Impact Assessment) Order 1989; and A Handbook of Environmental Impact Assessment Guidelines, 2000.

There is no definition of public participation. It has not been defined by the Aarhus Convention. The EIA Centre Review Paper has some idea about it. See EIA Centre, Consultation and Public Participation within EIA, University of Manchester, 1996, 2. 
development projects and will suggest certain measures to be taken that were not anticipated by proponents or the experts at the DOE.

In its widest possible form, thus, public participation is crucial in the decision-making for proper enforcement of law and bringing justice to door steps of a class of people, who might, directly or indirectly, be affected by the proposed activity and remain silent sufferers. ${ }^{12}$ Sometimes, projects have to be abandoned in view of the strong public opinion against them. For achieving these objectives, public awareness has to be a priority endeavour in matters essential with respect to the condition of the environment vis-a-vis developmental activities and strategies required for abatement and control of environmental degradation. It, along with other imperatives, has specifically been incorporated in the Convention on Environmental Impact Assessment in Transboundary Context $1991^{13}$ and the Convention on Access to Information, Public Participation in Decision-Making and Access to Justice in Environmental Matters 1998, which is commonly known as the Aarhus Convention and which is now of global importance. ${ }^{14}$ Among these international legal instruments, Aarhus Convention is of great importance. Despite the fact that at the time of the drafting of the convention it was not anticipated that it could be a useful instrument for making EIAs more realistic, the convention is significantly helpful in striking a meaningful balance between environment and development.

The purpose of writing this paper is to critically examine the public participating imperatives pertaining to EIA in Principle 10 of the Rio Declaration and the Aarhus Convention, ${ }^{15}$ which is a ground-breaking

12 See Jeremy Wates, Access to Environmental Information and Public Participation in Environmental Decision-making: UN ECE Guidelines - From Theory to Practice (EEB, 1995). Article 4 of the Convention makes distribution of the documentation to the authority and the public of the affected Party in the areas likely to be affected and their submission of comments' as a mandatory requirement in the process of making an EIA.

14 This may be noted that Aahrus Convention is a Convention of EU and European countries, but its treaty norms are of great importance to all countries of the world.

15 The treaty norms pertaining to public participation are mainly for the EU and European countries, but they have inherent value for making EIAs. For this reason, they are important in the Malaysian context 
legal instrument designed to advance environmental information, participation rights and access to justice. This paper also looks at the Malaysian EIA law with special emphasis on public participation, and offers useful and viable suggestions pertaining to public participation so that it becomes more efficient and serves the desired mission of sustainable development and protection of the environment through proper enforcement of the law.

\section{PRINCIPLE 10 OF THE RIO DECLARATION}

So as to affirm the cardinal sustainable development principle, Principle 10 of the Rio Declaration states, "Environmental issues are best handled with participation of all concerned citizens, at the relevant levels...At the national level, each individual shall have appropriate access to information concerning the environment that is held by public authorities ... and the opportunity to participate in the decision-making process. States shall facilitate and encourage public awareness and participation by making information widely available. Effective access to judicial and administrative proceedings, including redress and remedy, shall be provided."

This principle, thus, has four pillars: appropriate access to information; opportunity to participate in the decision-making process; enhancing public awareness; and effective access to judicial and administrative proceedings. By virtue of the first pillar, people should not only have access to information but the access should be appropriate, and the information should be widely available. The fourth pillar requires access to justice by providing opportunity to have access to both judicial proceedings and administrative proceedings. It means people should have freedom to institute cases without any technical or legal impediment. The author is of the opinion that this implies that with respect to environmental matters, the requirement of locus standi should be relaxed by the courts, where a larger group of people are affected or can be affected. It will be appropriate to leave the question of applicability of locus standi to the courts. Access to justice to administrative decisions

also. The Convention is open to accession by non-ECE countries, subject to approval of the Meeting of Parties. 
will require from the authorities of the DOE to take feedback from the public and to be transparent in decision-making. If the right(s) of the people at this level is violated, they should have right to invoke writ jurisdiction of higher courts of the country.

These pillars are applicable to both EIAs and SIAs. Many states, including Malaysia, have provided in their laws about application of these imperatives, but actual practices are not the same in all countries. ${ }^{16}$ The total picture is not so encouraging. In view of this, the UNEP Governing Council has requested states to intensify efforts and promote the four imperatives of Principle 10. In view of this, it is believed that states will improve upon the present conditions of public participation in environmental matters.

\section{AARHUS CONVENTION: A BASIS FOR PUBLIC PARTICIPATION}

As stated above, public participation in decision-making in an EIA process brings together developers, government authorities and the public that helps to clear up misunderstanding and hatches a better understanding of relevant issues, meets public needs, enhances access to environmental information, leads to better development decisions and results in fewer court cases because areas of controversy are identified and most of them are hammered out at the early stage of the development or planning process, minimises public frustration and anger, potentially enhances public trust of government decision-making, and strengthens credibility of the EIA regime. ${ }^{17}$ Cost and benefit study also reveals that public participation at the initial stage of a project saves both time and money. ${ }^{18}$ All countries know these facts, but very few of them give heed

16 See at: http://www.unece/env/pp/Rio10.UNEP.GC22.17.doc.

17 See J. Glasson, R. Therival and A. Chadwick, Introduction to Environmental Impact Assessment (London: Spon, 1999), 161; W. Tabb, "Environmental Impact Assessment in the European Community: Shaping International Norms,” Tulane Law Review, 1999, 953; Environmental Law Foundation, Aarhus Conference Law Report (London: Environmental Law Foundation, 2002), 6.

18 See European Commission, EIA: A Study on Cost and Benefits (Brussels: European Commission, 1996); Paul Stookies, "Getting to the Real EIA," Journal of Environmental Law, 2003, 15 (141). 
to these because they want to develop faster. The level of public participation can be chosen by states according to their suitability, but it is better to have it at the initial stage. However, if a country has provision for preliminary and detailed EIA reports, both should have requirement of mandatory public participation. For these, enough time should be provided. This has to be preceded by active as well as passive environmental information. It is worth noting here that in Berkley v. Secretary of State for Environment ${ }^{19}$ the court had rightly held that in a decision-making pertaining to an EIA, the public should be properly involved. Lord Hoffman stressed that the directly enforceable right of the citizen under the UK Directive on EIA ${ }^{20}$ was not merely a right to a fully informed decision on the substantive issue. It must have been adopted on an appropriate basis and that required the inclusive and democratic procedure prescribed by the Directive in which the public, whoever misguided or wrongheaded its views, would have been given an opportunity to express its opinion on the environmental issues. ${ }^{21}$ It is notable that the decision has a wide connotation. Proper public participation is imperative in cases where development, even at the local level, is to be proposed and carried out by a body of peoples' representatives. This decision of the House of Lords has a realistic approach.

Initially, those who opened EIAs for public comments did not receive encouraging response due to lack of enough environmental information and encouragement to the affected public and NGOs. These facts were noticed by the European Union. So as to have a realistic public participation in decision-making and access to justice, the Aarhus Convention was negotiated. ${ }^{22}$

As stated above, the Aarhus Convention, which had come into force on $30^{\text {th }}$ October 2001, instills and strengthens the participatory

\footnotetext{
[2000]3WLR 420.

20 EIA Directive 97/11/EC.

$21 \quad$ Ibid, at 430.

22 See W.A. Tillman, "Public Participation in the EIA Process: A Comparative Study of Impact Assessment in Canada, the United States and the European Community," 33 Columbia Journal of Transnational Law, 1 995, 337; S.H. Davis and N. Rukuba-Ngazi, Meaningful Consultations in Environmental Assessment, World Bank Social Development Notes, No. 39, 1998.
} 
democracy for sustainable development by making public participation as sine qua non in decision-making on environmental matters, by guaranteeing right of access to environmental information and by providing opportunity to access to justice. ${ }^{23}$ These have to be based on 'floor' not 'ceiling basis' and should be available free from fear or favour. It lays a sound foundation for ordinary people independently or through nongovernmental organizations (NGOs) to push the authorities for protection of the environment. In this context, suo motu participation of NGOs can also be of great importance. ${ }^{24}$

Access to information covers both 'active' and 'passive' information. Thus, authorities are duty bound to provide information on request, and also disseminate it to the general public by various means. In case a development plan is mooted, all environmental information is supposed to be provided to the general public living in the vicinity of the proposed project and might directly or remotely be adversely affected by it. If a person or a group of persons require any additional information, it has to be furnished. ${ }^{25}$ In this connection the following points are notable: 1. This right is available to all.

2. Information has to be provided as soon as possible. If justified, the time can reasonably be extended.

3. Information can be provided in any form.

4. $\quad$ Charges, if any, have to be reasonable.

5. Information can be denied if denial is in the interest of national defence, protecting international relations, ensuring public security, maintaining commercial confidentiality (except for withholding information on emissions which is relevant for the protection of the environment), protecting intellectual property right, or guaranteeing personal privacy.

6. Public interest is an important factor.

7. Refusal supported with reasons should be issued in writing.

8. In case of any dispute, the matter has to be referred to a higher authority.

$23 \quad$ See Article 1 of the Convention. See Aine Ryall, "Legislation Note Implementation of the Aarhus Convention through Community Environmental Law,” Environmental Law Review, 2004, 6.4 (274).

24 See Katy Brady, “Aarhus Convention Signed,” Environmental Policy and Law, 28/3-4 (1998).

25 See Article 4 of the Convention. 
9. Possibly, information should be released through the Internet.

10. Authorities have to be up to date and should regularly disseminate environmental information through regularly published reports or by any other suitable means.

The Aarhus Convention sets out certain essential requirements to enable the public to participate in various categories of environmental decision-making. Although it does not mention about public participation in EIAs, it may be considered as an essential policy instrument in the process of making them. ${ }^{26}$ In this context, the following points are notable: 1. The activities enlisted in Annex I of the Convention, which are similar to the list of activities for which an EIA or Integrated Pollution Prevention and Control Licence required under the EU legislation, are subject to EIAs and certain degree of public participation is required for them.

2. Public participation requires: timely and effective notification of the public concerned; reasonable timeframes for participation, including provision for participation at an early stage; a right for the public concerned to inspect information relevant to the decision-making free of charge; an obligation on the decisionmaking body to take due account of the outcome of the public participation; and prompt public notification of the decision, with the text of the decision and the reasons and considerations on which it is based being made publicly accessible. ${ }^{27}$

3. Authorities have to make a viable plan for an efficient public participation. ${ }^{28}$

4. There should be a time frame and provision for early participation.

One of the important aspects of the Aarhus Convention is access to justice. It has three dimensions:

1. Review with respect to information request.

2. Review with respect to project(s) decision-making that requires public participation.

\footnotetext{
$26 \quad$ See Article 6 of the Convention.

27 See the UNECE website at <http://www/.unece.org/env/pp/ contentofaarhus.htm>.

$28 \quad$ See Article 7 of the Convention.
} 


\section{Challenges to breaches of environmental law. ${ }^{29}$}

Among these, the third point is the most important as it provides redress opportunity to aggrieved persons who have objected to any project or who have suggested substantial changes in the EIA report and the authority concerned either ignored them or gave little importance to them. There can be an appeal to the higher administrative authority, including the Minister; or the aggrieved persons may go to the regular court of justice. ${ }^{30}$ Article 9(5) aims to address concerns over the high level of expense often associated with review by courts. To this end, the Convention requires that each Party to the Convention to consider the establishment of what are described as 'appropriate assistance mechanism' in order to 'remove or reduce financial and other barriers to access to justice.' Presumably, this provision contemplates some form of legal aid or other financial assistance and expert assistance. ${ }^{31}$ The Aarhus Convention does not preclude the affected parties from opting for speedy justice like public interest litigations, which are common in India, the Philippines and many other countries, where locus standi is relaxed in matters of the interest of general public. It means in such situations, a case can be brought by an NGO or individual environmentalist for protecting the interests of the public who are affected or might be affected by any proposed project of development. If the case is brought by an individual or a group of individuals or an NGO or a group of NGOs, the poor sufferers are relieved of all kinds of financial burden of the litigation.

The treaty norms of Aarhus Convention presumably provide a basis for streamlining public participation imperatives in EIA laws with respect to local developmental plans and other developmental activities in all countries. This has been stated in point 40 of the declaration at the close of the Ministerial Conference on the Aarhus Convention in the following words, "We regard the Aarhus Convention, which provided recognition for citizens' right in relation to the environment, as a significant step forward both for the environment and for democracy. We encourage all non-signatory states to take appropriate steps to become parties to

\footnotetext{
$29 \quad$ See Article 9 of the Convention.

30 For more on the contents of the Aarhus Convention, refer to the 'implementation guide' at the UNECE website.

$31 \quad$ See Aine Ryall, ibid., n. 23.
} 
the convention." ${ }^{32}$ The Convention has been hailed by political leaders as an ambitious venture in environmental democracy provided the three aspects detailed in the Convention are properly adhered to. ${ }^{33}$ Kofi Annan, the former Secretary General of the United Nations put this as: "Although regional in scope, the significance of the Aarhus Convention is global. It is by far the impressive elaboration of principle 10 of the Rio Declaration, which stresses the need for citizen's participation in environment held by public authorities. As such it is the most ambitious venture in the area of environmental democracy so far undertaken under the auspices of the United Nations." ${ }^{34}$ At the discussion session, the Denmark's Minister for Environment and Energy remarked that the Convention laid a sound foundation for ordinary people to push for environmental progress in all of our countries. He further said that criticism was essential to democracy...to direct the process of involvement, to give voice to the general public, inspiration to political parties and governments and to provide an informed critical, corrective, NGOs involvement is essential. ${ }^{35}$ However, the right can best be ensured to the general public, especially the affected people, by active information dissemination, meaningful participation of the public concerned and efficient involvement of NGOs. Mary Robinson, United Nations High Commissioner for Human Rights, in her keynote address, which was distributed at the NGO session, also stressed on these aspects. She wrote: "To secure that (fundamental right) we need to have access to environmental information and so I welcome the proposed convention making such access binding - and I look forward to the implementation of the details of the convention. We do not need fine rhetoric or well-written conventions that gather dust; we need determined, immediate and true follow up to the expressed wishes of the parties involved. With proper access to information I believe that there

$32 \quad$ See Katy Brandy, “Aarhus Convention Signed,” Environmental Policy and Law, 28/3-4 (1998), 171-189.

33 See Alexios Antypas, "A New Age for Environmental Democracy: The Aarhus Convention in Hungary,” [2003] 6 Environmental Liability, 199-208; E. Petkova, C. Maurer, N. Henninger and F. Irwin, Closing the Gap: Information Participation, and Justice in Decision-making (Washington D C: World Resources Institute, 2002), 20-39.

34 It has been cited in United Nations Economic Commission for Europe Press Release of 29 October 2001 'Environmental Rights Not a Luxury. Katy Brandy, ibid., n. 32. 
will be a dramatic increase in the demand for public participation in environmental decision-making. The opportunity for the public, individuals or more usually NGOs, to become involved must be built in so as to allow full participation from the beginning of the process e.g., in the scooping of an environmental impact statement and not just in commenting on it if once completed. This will put demands on national and local authorities but it will also lead to better environmental management and to sustainable development. Another meeting points of the rights is in the area of access to justice...I regard NGOs as having a public interest 'watch dog' is vital in all our societies and is in need of our strong support." 36

The decision on conclusion of the Aarhus Convention by the EC was adopted on 17 February 2005 by 'Decision 2005/370/EC'. It became a party to it in May 2005. The treaty norms of the Aarhus Convention have been enforced by the EU through its Directive 2003/35/EC and 'Directive 2003/4/EC.' With the result of that the Directive 85/337/EEC on EIA, which had been earlier amended by Directive 97/11/EC. On 24 October 2003, a proposal for a Directive of the European Parliament and of the Council on Access of Justice in environmental matters was presented. This proposal was the part of the 'Aarhus Package.' This was adopted in September 2006. ${ }^{37}$

The new Directives are being enforced in EU countries via necessary amendments in relevant legislations. Thus, in England for example the Town and Country Planning (Environment Impact Assessment) (England and Wales Regulations) 1999 has suitably been amended. The norms are being given effect by courts also. For example, in $R$ (on the application of Hareford Waste Watchers Ltd.) v. Herefordshire County Council ${ }^{38}$ the claimant company had been formed to oppose the construction of a waste-treatment and recycling facility in an industrial estate. Following the submission of a planning application, the Council granted full planning permission, subject to conditions. This was objected on the ground that relevant information was not provided to the affected persons. Elias J quashed the planning permission saying that the Council had not conclusively found that the development would not have significant environmental effect. The authorities were wrong to

36

Letter from Mary Robinson to the Conference delegates, 19 June 1998. Quoted from Katy Brandy, ibid., n. 32, at 171. See at: http;//ec.europa.eu/environment /aarhus/index.htm. [2005] EWHC 191 (Admin); [2005] PLSCE 29. 
grant permission subject to conditions. Article 3(2) of the 1999 Regulation provides that the planning authority should not grant planning permission 'unless they have first taken the environmental information into account. ${ }^{39}$ However, the British courts have ruled in a number of cases that where an appropriate body comprising representatives from the public makes decision concerning development, public participation is not necessary. ${ }^{40}$ The case of $R$ v. Secretary of the State for the Environment, Transport and the regions (ex parte Alconbury) ${ }^{41}$ reminded this by saying that it was the role of the elected representatives to take decision on behalf of the local communities they represent. The author is of the opinion that this is no more tenable in light of the Aarhus Convention. European countries that have not yet been brought within the fold of the European Union but are members of the Aarhus Convention are also enforcing the treaty norms by making suitable laws or by making required amendments in the existing legislations. ${ }^{42}$ It can now be said that due to cost hikes and delay of projects, in many cases, proponents are in a hurry and want the projects started soonest possible. In some cases, authorities also want to start certain projects without any delay, and some times prefer developments on environment or/people. In spite of this tendency, in a large number of cases, the benefits of undertaking EIAs were unimaginable, and with the result of those interests of the environment, its processes and people benefiting from them could be protected. The Aarhus Convention and regulations made for enforcing its treaty norms will further enhance the EIA process, and due to vigorous public participation, these interests will further be augmented. In the whole process, the role of the policy makers is central. It is their responsibility to provide active and passive information, provide opportunity of participation, most appropriately by bringing together relevant authorities, proponents of development and the public, to be affected and others. They will ultimately give the input of the meeting(s) into EIAs and SIAs.

$39 \quad$ For a detailed account, see “All the Latest on EIA,” Estates Gazette, 14 May 2005, 1-3.

See Paul Stookies, “Getting to the Real EIA,” Journal of Environmental Law, 2003.15(141); "Case Law Analysis - The EIA Process and the Directly Enforceable Rights of Citizens,” Journal of Environmental Law, 2001, 13 (89).

$41 \quad$ [2001]UKHL 23.

$42 \quad$ See Alexios Antypas, “A New Age for Environmental Democracy: The Aarhus Convention in Hungary,” ibid., n. 33. 
Based on above paragraphs, it can be said that the three pillars of the Aarhus Convention are essential tools for ensuring sustainable development. Public participation can make environmental decisions more realistic; and in case of arbitrariness in the decision-making process, people can resort to courts for justice. Although the Convention has specifically been made for EU countries, other countries, including Malaysia, can also become its members. Likewise, although it does not specifically mention about EIAs, it will be appropriate to apply the three pillars in the process of making EIAs and SIAs.

\section{MALAYSIAN POSITION}

\section{Legal Framework}

As stated above, in Malaysia, an EIA exercise has to be done in accordance with section 34A of the Environmental Quality Act 1974 (hereinafter 'EQ Act') ${ }^{43}$ and the Environmental Quality (Prescribed Activities) (Environmental Impact Assessment) Order 1989 (hereinafter referred to as 'the EIA Order'). ${ }^{44}$ Section 34A requires the proponent to submit a report(s) to the Director-General, prepared in accordance with the guidelines made by the Director-General, containing the assessment of the possible adverse impact on the environment, the proposed activity that it will have or is likely to have on the environment and the proposed measures that will be undertaken to prevent, reduce or control the adverse impact if any. The Director-General may approve it with or without any conditions, or may disapprove it. Disapproval does not preclude the proponent from revising and re-submitting the report. The section entails that with respect to prescribed activities, which are there in the EIA Order and with respect to which EIA is a mandatory requirement; work cannot be started unless the EIA report is approved. The EIA Order prescribes with some exactitude 19 items containing 58 activities with respect to which EIA is a mandatory requirement. These activities have mandatory EIAs because they are more likely to leave adverse effects

\footnotetext{
$43 \quad$ Act 127.

$44 \quad$ PU (A) 362/1987. It came into force on $1^{\text {st }}$ April 1988 and amended by PU (A) 117/1995, 44/1996, 489/2000.
} 
on the environment and/or on the public. Section 34A of the EQ Act does not mention about public participation. It is a necessary requirement in 'A Handbook of Environmental Impact Assessment Guidelines' (hereinafter referred to as the EIA Handbook) ${ }^{45}$ and Environmental Impact Assessment Guidelines for Risk Assessment (hereinafter referred to as the Risk Assessment Guidelines) ${ }^{46}$ prescribed for preparing EIAs and risk assessments and getting them approved by the Director-General. In Malaysia, since land is a state subject, some states have also thought of having their own EIA regime. So as to have uniformity, the Federal Government requested such states to follow the Federal law so that uniformity of law is maintained throughout the country. Sarawak made its own law as section 11A(1) of the National Resources and Environment Ordinance of 1993. Under this Ordinance, Sarawak Natural Resources and Environment (Prescribed Activities) Order 1994 was made and 'A Handbook of the Basic Policy and Procedure of Environmental Impact Assessment in Sarawak' was issued. Like Sarawak, Sabah has section 5(1) of the Conservation of Environment Enactment and the Conservation of Environment (Prescribed Activities) Order 1999. Sarawak's law has a marked difference from the Federal law, as it does not provide for public participation in the EIA process. Since EQ Act and EIA Guidelines made under it are applicable to the whole country, activities that are not covered by the Sarawak law and Sabah law fall under the purview of the Federal law. This was clarified in the year 2000 by amending the EIA Order. ${ }^{47}$ However, with respect to certain activities mentioned in paragraph 4 of the EIA Order, the Order remained applicable.

$45 \quad$ The latest guidelines are of December 2000. It is notable here that to facilitate preparation of EIA reports in various activities, separate guidelines have also been prescribed. These guidelines supplement the EIA Guidelines.

The latest guidelines are of December 2004. In Malaysia, Social Impact Assessment is subsumed in Risk Assessment. It is done in case of major hazardous industrial installations defined as: "facilities that store and process large amount of flammable and /or toxic materials having the potential to cause adverse consequences to the surrounding population, property and environment.” See paragraph 1-1 of the Risk Assessment Guidelines.

$47 \quad$ The old paragraph 3 was substituted by a new paragraph, and a new paragraph 4 was introduced by $P U(A) 489 / 2000$. 
As a matter of general procedure, the proponent has to get a preliminary report prepared according to Chapter 2 of the EIA Handbook. This is followed by a detailed report if the proposed activity falls within the activities for which detailed reports are necessary to be made according to chapter 3 of the EIA Handbook. Alternatively, the proponent can go straight away for the detailed EIA report. All reports have to be submitted to the DOE and have to be examined by the experts of the department. Suggested changes are forwarded to the proponents. They are resubmitted with required changes, and finally forwarded to the DirectorGeneral of the Environment for approval. As stated above, EIA reports can be accepted with or without any conditions to be complied with by proponents. There are provisions for reporting back about the compliance of conditions and about proposed measures to be taken to prevent, reduce or control the adverse impact on the environment incorporated into the EIA report. On contravention, the proponent will be found guilty under section 34A of the EQ Act and will be liable to a fine not exceeding RM100,000.00 or to imprisonment for a period not exceeding 5 years or both.

The number of EIA reports submitted by proponents is fast increasing. ${ }^{48}$ For proper compliance of the law and for achieving the object of the EIA regime, the Ministry of Natural Resources and Environment will soon set up a panel of consultants to assess all EIA applications. Under the old law, on non-compliance of the conditions appended with approved EIAs, the offender was subjected to suitable penalty prescribed under section 34A, and in most of the cases, they were subjected to fine, which they could easily pay and carry on flouting the law. According to the Deputy Minister of the Ministry of Natural Resources and Environment, even a hefty fine has not done the job. ${ }^{49}$ The position has changed now. Under the changed law, a stop-work order can be issued if conditions appended to the EIA are not followed. According to the author, in view of rising prices, a stop-work order will

\footnotetext{
48 See the website of the Department of Environment at: http:// www.doe.gov.my. In 1997-98, because of economic downturn the number was comparatively less.

$49 \quad$ See New Straits Times, 3 June 2005. In the past, a stop-work order could be issued only by the local authority, which exercised this power in very few cases.
} 
have a greater degree of deterrence, which will certainly result in proper compliance of the conditions. The author opines that a stop-work order should be made part of the substantive law by making suitable amendments to section 34A of the EQ Act. A stop-work condition should specifically be mentioned in all approved EIAs, where they are appended with necessary conditions to be followed during the executions of the work. The author is also of the opinion that affected people will now be encouraged to come forward and inform the authorities about violations of conditions appended with EIAs.

\section{Public Participation}

Similar to the Aarhus Convention, paragraph 1.4.5 of the EIA Handbook considers public participation as a valuable aid to the project planning to monitor community needs, to identify material and psychological impacts on the community, to measure public acceptance of the project, to avoid costly modifications or abandon the project, to monitor changing environmental values in the community, and to obtain additional environmental information known to the local people. In view of these, paragraph 1.6.1(d) states that some kind of public participation is necessary to be there in both preliminary and detailed EIA reports.

With respect to Preliminary Assessment, the EIA Handbook says that some kind of public participation is essential. It provides for three modes of public participation: (a) Public Opinion Sampling - this survey has to be carefully planned and managed to obtained useful suggestions. (b) Public Meetings or Workshops - these are advised to be organized to cover a wide range of issues. (c) Regular Meetings with Citizen Committees - this is useful in planning and development of large projects over an extended period, provided the committees are truly representing the affected communities. ${ }^{50}$

Pertaining to Detailed Assessment, the EIA Handbook says that public participation must be included and provides for three modes to be adopted: (a) Citizens Committees - There should be regular meetings between project planners and Citizen Committees over an extended period if the project is big. The committees should truly represent the cause of 
affected communities. (b) Public Meetings and Workshops - These can be used to hammer out issues pertaining to large projects. (c) Public Opinion Sampling - It can be useful if the environmental issues arising from the proposed project are simple. It can be also used to reach a large or diverse people if carefully planned and managed to obtain useful suggestions from them. ${ }^{51}$

The EIA Handbook generally says that some kind of public participation is necessary for both Preliminary Assessment and Detailed Assessment. However, for Preliminary Assessments, the word 'essential' has been used. Contrary to this, with respect to Detailed Assessments, the word 'must' has been used. However, the modes of public participation prescribed are more or less the same. We can infer from these, that the EIA Handbook lays more emphasis on public participation with respect to Detailed Impact Assessments. This is understandable because the activities to which Detailed Assessments have been prescribed have more probability to leave adverse effects on the environment or the community or both. In practice also the DOE is keener to see the outcome of public participation and their inputs in the Detailed Assessment reports submitted to the Department, as in case of Detailed Assessments, the reports have to be opened for public comments to be made in writing within 45 days. This is because EIAs are done to protect the environment, its processes and the people who can or might be affected by the proposed project, so that a meaningful balance between environment and development could be created. It is only due to proper and meaningful public participation that the law will properly be enforced and the interests of the environment and the public interest can be cosseted. In absence of this, there will not be proper enforcement of law, which might be seriously deleterious to the environment and catastrophic to the lives of the people, and their economy. This is not in the case of Preliminary Assessment. In this case, there has to be public participation, but it has to be collected and presented by the project proponent. For this reason, it is well understood that with respect to Preliminary Assessment, public participation cannot be realistic.

In view of this, it can be said with utmost determination that a significant public participation is sine quo non for proper enforcement of the EIA law both for Preliminary Report and Detailed Report. All 
efforts, therefore, should be made by the DOE to ensure that this aspect of law is given due consideration in all developmental activities with respect to which EIA is a necessary requirement. In no circumstances, public participation or, for that matter, EIA should be taken for granted. In many developing countries, in some exceptional situations, it has happened that development was given priority over protection of the environment. But due to enhancement in environmental education, which ultimately results in environmental consciousness, has fast alleviated this practice.

In the EIA Handbook, there is a welcome prerequisite that all Detailed Assessment reports have to be displayed in full by the project proponent at the Department of Environment office of the state and at its main office, unless it is not in the national interest or violates proprietary rights. ${ }^{52}$ Reports have to be in Bahasa Malaysia and English. It has to be notified through newspapers of two languages. Reports should be available to public on a price to cover printing and postage charges. If so requested, it should be sent by post. This will greatly benefit the project proponents as it results in overall time saving in project planning and better decision-making as a result of more information..$^{53}$ This will provide opportunity to the general public, including NGOs, to express their constructive views on proposed projects. The EIA Handbook states that the 'Jawatankuasa Keselamatan dan Kemajuan Kampung (JKKK) and local Rukun Tetangga Committees might be suitable for this purpose. ${ }^{54}$ It does not specifically mention about involvement of NGOs. The author is of the opinion that participation of NGOs is rather essentially warranted for proper enforcement of the public participation provision in the EIA law. It is notable that participation of NGOs, specifically of the Consumer Association Penang (CAP), has been of immense value in a number of cases. ${ }^{55}$ It is also notable that for these, it is the duty of the project

52 Paragraph 3.4 .7 of the EIA Handbook rules: "If a project initiator believes that, in the national interest or due to proprietary rights, a part of the Detailed Assessment report should not be made available to the public, he can apply to the Director General of the Environment for the information to be withheld from public scrutiny." Department of Environment, Malaysia Environmental Quality Report 1996, 50.

$54 \quad$ Paragraph 3.4.4 of the EIA Handbook.

55 See infra. 
proponents. The author supports the view that the whole process of public participation should be carried out under the auspices of the Department of Environment. In addition to the present scheme, it will be better if the Department organises joint meetings of the officials of the Department, people to be affected, including NGOs and project proponents. Joint meetings are already in practice for finalising development plans and have proved to be an effective tool to properly enforce sustainable development imperatives. ${ }^{56}$

We have noted above that in case of Major Hazardous Industrial Installations, risk assessment is also necessary to be done so that the likelihood of adverse effects on humans and deleterious effects on the environment through qualitative and quantitative predictions could be made and mitigating measures could be adopted. With respect to such installations, therefore, risk assessment is also being done. Although the Risk Assessment Guidelines do not mention about public participation, it is notable that the Risk Assessment Report has to be submitted along with the EIA Report hence it will have to pass through the whole process through which the EIA Report will pass. Thus, public participation becomes a necessary requirement for this also. However, the author is of the opinion that for the sake of surety of public input in the Risk Assessment Report and for proper enforcement of law, there should be specific provision about public participation in the Risk Assessment Guidelines also. In this, the role of NGOs can be of immense value.

In spite of the legal requirement, the level of public participation has been too low. In 1998, on 12 detailed EIA Reports processed by the DOE, a total of only 13 written comments from the public were received. ${ }^{57}$ This is a pessimistic figure. The position has not significantly changed. In Malaysia, public participation with respect to open burning, haze and illegal waste disposal has been praiseworthy. It means that the Malaysian public is fairly aware of environmental matters. Here the following questions arise: Why are people not coming forward to freely express their opinions on Detailed Assessment Reports when kept open for public comments? Should we follow the treaty norms of the Aarhus Convention? Are officials of the Department of Environment taking enough pains to

\footnotetext{
$56 \quad$ See infra.

$57 \quad$ It may be noted that after 1998, the Environmental Quality Reports do not have such data.
} 
ensure public participation or depending on the information furnished by proponents?

We have noted above that the three aspects of the Aarhus Convention - Active and passive dissemination of environmental information, public participation in the decision-making and upholding the right to judicial review - are not binding on non-member states, but many of these states are more or less following these three imperatives of public participation in developmental activities. Malaysia is also intimately following them. The Department of Environment for disseminating environmental information, for promoting environmental education and creating public awareness is doing a commendable job. Some of them are: organising extracurricular school activities, holding Wira Alam - which is a student awareness programme regularly organised in collaboration with Malaysian Nature Society, organising environmental awareness camps, encouraging environmental scrap book competitions, interuniversity environmental debates, environmental poetry competition, supplying environmental educational materials such as posters, videos, bulletins, fact-sheets, environmental songs, patronising a number of activities organised in the Malaysian Environmental Week, promoting environmental awareness through the mass media, instituting the Langkawi Award, Malaysian Ozone Layer Protection Award and Environmental Journalism Award, and establishing cooperation for environmental awareness with the Junior Eco-Club of Japan, UNEP Young Environmental Envoys Protect and ASEAN Working Group on Environmental Information, Public Awareness and Education.

These efforts have immensely contributed to dissemination of environmental information and bringing about awareness among the general public. The effect of environmental awareness has conspicuously been noticed during haze conditions in the country. People are also coming forward to complain about illegal dumping and open burning. But the response of the public, in general, has been lackadaisical on Detailed Assessment reports, especially of those who can or might be affected by proposed activities. Sahabat Alam Malaysia in Malaysian Environment in Crisis (1994) puts it as: "Despite the usefulness of the EIA process on paper, it has lost most of its impact on the ground to protect the environment. After over a dozen years of experience with EIAs, many environmentalists and concerned citizens have begun to express frustration with the process, while many developers view EIAs 
as mere formality to be complied with. Approval for EIAs comes from the inadequately staffed and budget-strapped DOE. EIA approval for controversial projects...gives rise to public perception that pushes for high level government projects can exercise undue influence on DOE in discharging its duties to citizens and the environment." ${ }^{58}$ It further states: "Unfortunately, all too often bulldozers start to rumble before the final EIA has properly addressed preventive measures and allowed the public to state their views... access to EIA reports is limited both in terms of time and copies available and the outcome of public feedback in decisionmaking is unknown...the lack of effective public participation does not result from lack of interest but due to poor sharing of information and inadequate notification on the part of the DOE." ${ }^{59}$ An assessment by the then Ministry of Science, Technology and Environment in 1997 stated that "the lack of specific legal provisions relating to the timing of submission of the EIA needs to be addressed if this provision is to be seriously enforced." ${ }^{60}$ The author does not wish to argue to substantiate Sahabat Alam Malaysia's grudge with respect to EIAs. But if we look at the EIA process of the Bakun Dam Project (see infra) and the development activities in Cameron Highlands, ${ }^{61}$ they seem to be partially correct. The Bakun Dam Project was one of the largest projects in the country with massive environmental repercussions and displacement of around ten thousand households. Public participation was not allowed, as the Court of Appeal ruled that the Dam was situated in Sarawak, and

$58 \quad$ At 162.

$59 \quad$ At 163.

60 Sahabat Alam Malaysia, Malaysian Environment in Crisis, 163. Similar views have also been expressed by some experts about the EIA regime and public participation in some other countries. Anne Shepherd and Christi Bowler say, "Citizens involvement is often to a procedural exercise instead of a substantive process to include the public in environmental decision-making.” They suggest that going beyond the minimum requirement of public participation is even better. See A. Sheppard and C. Bowker, "Beyond the Requirements: Improving Public Participation in EIA,” The Journal of Environmental Planning Management, Vol. 40, No. 6, 1997, 725-738, at 730. John Glassan, Andrew Chadwick and Thrieval Rutledge also hold similar view. See Introduction to EIA (Rutledge: UK, 1999).

$61 \quad$ See New Sunday Times 24 April 2005. 
for EIA, the law of Sarawak would apply which did not provide for public participation. ${ }^{62}$ This brought surprise and disappointment to some environmentalists and legal experts. ${ }^{63}$

For meaningful public participation, the DOE should make proactive efforts encouraging the people and NGOs to come forward and advance useful suggestions. The author re-iterates that it will be better if joint meetings of the three stakeholders are held before the project is allowed to go ahead and people who are directly or indirectly affected are encouraged to express their feelings. It will be in the interest of sustainable development and proper enforcement of the EIA law if NGOs are allowed to speak on behalf of these people. The DOE should also ensure that useful suggestions are given due consideration. In no case, should the EIA be taken for granted. Thus, for public participation in EIAs, project proponents and the DOE should work jointly. It is not difficult now, as the DOE has its office in almost all states and it can easily coordinate public participation thoroughout the country. So as to do proper scrutiny of Assessments, collecting public suggestions and ensuring their incorporation into the final EIA Reports, there have to be enough and properly trained personnel. We have noted above that the Government is proposing to have a panel of experts to evaluate all EIAs. It is a welcome move. With respect to mega or high-risk projects, the DOE should take help, as it took in the Bakun Dam project, from foreign experts. This will help enforce the objectives of EIAs and will generate confidence among the people. We have also noted above that under the new law, a stop-work notice will be issued by the Department of Environment. This is also a welcome change. In this regard, public participation is also significant. They can bring the matter to the notice of the DOE and the Ministry in manifest ways. The examples of the Bukit

\footnotetext{
62 See Ketua Pengarah Jabatan Alam Sekitar \& Another v. Kajing Tubek \& Ors, [1997] 3 MLJ 23. Comparison of Planning Law in Malaysia and England," Environmental Law Review, 2003, 5.4 (231); Gurdial Singh Nijar, "The Bakun Dam Case: A Critique,” The Malayan Law Journal, [1997] 3 MLJ ccxxix; Meenashi Raman, "Environmental Law and Litigation in Malaysia: A Perspective from the Ground," paper presented at the Commonwealth Law Teachers Conference, October, 1999, Malaysia.
} 
Cahaya Project ${ }^{64}$ and pollution of water due to landfills close to rivers and water catchments ${ }^{65}$ are notable examples.

The Malaysian courts can also play a proactive role for providing opportunities to the people to participate in developmental activities. In Ketua Pengarah Jabatan Alam Sekitar v. Kajing Tubek, ${ }^{66}$ the Court of Appeal instead of applying the EQ Act and the Environmental Quality (Prescribed Activities) (Environmental Impact Assessment) Order 1987, applied the laws of Sarawak namely, the Natural Resources Ordinance 1994 and Natural Resources and Environment (Prescribed Activities) Order 1994, which did not provide for public participation. Justice Gopal Sri Ram and Justice Mokhtar Sidin ruled that since the 'environment' in question, by reason of item 2(a) of List II and item 13 of List IIIA of Schedule 9 to the Federal Constitution, lay wholly within the legislative and constitutional province of the State of Sarawak, that state had exclusive authority to regulate, by legislation, the use of it in such manner as it deemed fit.' ${ }^{67}$ This is because of the courts' strict adherence to the statutory law and their narrow applications. The position is almost the same in the Town and Country Planning Act 1967. Under this Act, with few exceptions, the law contained in sections 9, 12(A), 13 and 21(8), have been given strict application. Thus, courts seem to have failed to play that role. The following cases may be referred to: Abdul Razak v. Kerajaan Negeri Johor \& Anor; ${ }^{68}$ Laila Dulcie Allana Labrooy \& 9

64 When shocking pictures of forest areas around the Bukit Chahaya Seri Alam Agricultural Park stripped bare for development were splashed across the front pages of newspapers in 2005 and when public objected to the development activities, which unnecessarily destroyed a large area of forests, the government had to take necessary action against the developers in the area. See New Straits Times, 4 March 2004. Also see Elizabeth John, “Actually, It’s,” New Sunday Times, 10 April 2005. This resulted in increase of ammonia in the drinking water supplied to residents. The affected residents staged a huge protest against it. This resulted in many landfills being closed down, and a policy was developed that from now on landfills will be far form rivers and water catchments and this will be ensured by appropriate EIAs. DOE found that there was clear violation of EIAs. See New Straits times, 12 March 2006.

$66 \quad$ [1997] 3 MLJ 23.

67 See 38E, I and 39A, E of the case.

68 [1994]2 MLJ 297. 
Ors v. Majlis Bandaraya Ipoh and Anor; ${ }^{69}$ Epco Marine Sdn. Bhd. v. Yang Di Pertuan Majlis Perbandaran Pulau Pinang \& Anor; $;^{70}$ Datin Azizah bte Abdul Ghani v. Dewan Bandaraya Kuala Lumpur 7 Ors $;{ }^{71}$ Zain Azhari Bin Zainal Abidin v. Datuk Bandar Kuala Lumpur;72 Lee Freddie @ Lee Long Koi 7 Ors v. Majlis Perbandaran Petaling Jaya \& Anor; $;^{73}$ Abdul Razak Ahmad v. Kerajaan Negeri Johor \& Anor; ${ }^{74}$ Abdul Razak Ahmad v. Ketua Pengarah Kementerian Sains, Teknologi dan Alam Sekitar. ${ }^{75}$ In the last case, the court granted to the plaintiff the right to view the environmental impact assessment report of the development project undertaken by the state government, as he was found to have locus standi to participate. Right to public participation was clearly recognized by the court in Kajing Tubek \& Ors v. Ekran Bhd. \& Ors. ${ }^{76}$ The author is of the opinion that the courts should have given a liberal interpretation of the provisions contained in the Environmental Quality Act 1974 and the Town and Country Planning Act 1976 as this will serve the object for which public participation in development and planning processes are required. This will also be, in a way, enforcement of the treaty norms of the Aarhus Convention.

In Malaysia, although locus standi is the requirement, people have resorted to justice with the help of NGOs. This way, many have been able to get redress.

To conclude, in Malaysia, the EIA regime contains the three requirements of public participation set out by the Aarhus Convention. The need is to further enhance them and properly enforce them so that development activities become really sustainable. There are cases where

\begin{tabular}{ll}
\hline 69 & [1995] 4CLJ 727. \\
70 & {$[1993]$ CLJ 446. } \\
71 & {$[1992] 2$ MLJ 393. } \\
72 & {$[1995] 2$ CLJ 478. } \\
73 & {$[1994]$ 3 MLJ 640. } \\
74 & {$[1994] 2$ MLJ 297. } \\
75 & {$[1994] 2$ CLJ 363. } \\
76 & [1996] 2 MLJ 388. Unfortunately, this case has been reversed by the \\
& Court of Appeal in Ketua Pengarah Jabatan Alam Sekitar v. Kajum \\
& Tubek [1997] 3 MLJ 23, discussed above. For a critical appraisal of this \\
& case, see Gurdial Singh Nijar, "The Bakun Dam Case: A Critique," \\
& Malayan Law Journal [1997] 3 MLJ ccxxix.
\end{tabular}


public participation has resulted in either abandoning the proposed projects or to bring about substantial changes in the EIAs. As a matter of last resort for obtaining environmental justice, aggrieved persons have also gone to the courts.

\section{Case Study}

In 1991, there was a proposal to carry out further development on Penang Hill. There was public outrage about the proposal, which was expressed by various means. On the Detailed Assessment report, the DOE received 419 written comments within the stipulated time. ${ }^{77}$ The DOE received 953 written comments even after the closing date. ${ }^{78}$ Almost all written comments were against further development on Penang Hill as it could have destroyed the flora and fauna of the hill. It is also notable that the Hill is too steep to suggest any development. As a result, the project was dropped. Due to support of NGOs such an active public participation could be possible. The whole episode accentuates the fact that an effective and realistic public participation can help in enforcing the law. It is widely accepted that development on steep (of certain degree) hills should not be carried out. It is more so if for development, flora and fauna have to be sacrificed. It is needless to mention here that trees on hills along with others, serve two significant purposes: one, protecting the soil from erosion and water absorption. Public participation helped to enforce this. People are environmentally conscious enough to understand destruction of the environment that a project on the Penang hills can possibly cause. They will not support any development even if the government wishes to support it with an EIA, as it will destroy the rich biodiversity of the hills.

In 1999, there was a proposal to build a dam on Sungai Selangor. Environmentalists and the public vehemently opposed this proposal, ${ }^{79}$ as it had to destroy the second largest firefly colony of the world, and it had to displace a large number of people. There was a widespread all-out

\footnotetext{
77 Department of Environment, Environmental Quality Report, 1991, 130.

$78 \quad$ Ibid

79 See New Straits Times, 16 March 1999; The Star, 9 September 1999.
} 
protest against this proposal. It was suggested that Pahang state has surplus water and water can be brought through pipes from there. With the result of that more than 200 written comments and 10,000 signatures were received by the DOE. ${ }^{80}$ These written comments were not given heed. The Director General said that there were only 18 genuine comments and approved the EIA.$^{81}$ In the whole episode, SOS Selangor, which is a coalition of NGOs, was very active. They suggested that the water in the Klang Valley was sustainable. The resentment of the Orang Asli people continued. They are stressing about their insufficient income. This might help them.

In this case, the peoples' concerns were not given heed by the government; maybe, because the DOE did not find them to be of great importance. However, this paved the way for future public participation. The author is of the opinion that in such a situation, the opinion of the experts of the International Union for Conservation of Nature (IUCN) should be taken.

The incinerator project of Broga, Semenyih is yet another example of active public participation. So as to solve the waste-dumping problem, the Government of Malaysia decided to have a huge incinerator with the financial support of Japan. ${ }^{82}$ From the very beginning, residents of the area with the help of some NGOs, objected to the plan. The matter was

80 See Cheng Lai Tan and S.S. Yoga, "Dam EIA draws flood of response," The Star, 20 April 1999; Rajeshwari Kanniah, "Public Participation in the Environmental Impact Assessment Process in Malaysia," Malayan Law Journal, [2000] 3 MLJ cxxxiv. Also see the website of Save Our Sungai Selangor at: http://www.sos-selangor.org/case-p8.htm; Orang Asli (aborigines of Malaysia) people also spoke against the proposal. They have been relocated, but there sufferance persists. See Shane Randhawan, "Selangor dam: a cause for concern," Malaysiakini.com, at: http://www.malaysiakini.com/letters/27503.

$81 \quad$ New Straits Times, 1July 1999.

82 Incinerator(s) are a necessary requirement of the Klang Valley. All developed countries have incinerators. Singapore has four incinerators. The only thing that has to be properly taken care of is that residents around the incinerator must be safe. This is possible only when dioxine and heavy metals are not there in the emissions from the incinerator, and there is a buffer zone. So as to see the effect of the project, regular monitoring by competent experts is also necessary. In absence of these, no incinerators should be allowed to operate. 
undertaken by some international NGOs also. Global Anti-Incinerator Alliance demanded that Japan should not financially support the project. IPEN (International POPs Elimination Network) requested Dr. Mahathir, the then Prime Minister, to stop the project. Detailed Environmental Assessment was done, but the project was put in abeyance for a short time. In the mean time, there were meetings and briefings by the Housing and Local Government Ministry, which failed to convince the residents. Their main concern was about dioxine and heavy metals that is the usual emission from incinerators. They obtained arguments from NGOs. ${ }^{83}$ Ultimately the Director General approved the EIA and the project received the go-ahead from the DOE subject to six conditions to be complied with during the operation of the incinerator. The six conditions, appended to the EIA report, were actually the result of the public outrage, because due to this the Government had to promise that the incinerators would comply with international standards. The six conditions are:

1. A $1500 \mathrm{~m}$ buffer zone free of any human habitation around the incinerator has to be created.

2. Chimneys must be at a minimum height of $150 \mathrm{~m}$.

3. The pant must use 'fluidised-bed type gasification' and ashmelting technology, complete with air pollution control and energy recovery system.

4. Scheduled sampling and analysis of important parameters on gas and particulates emitted from chimneys such as for dioxine and heavy metals must be carried out.

5. Gas and particulates must be at acceptable levels.

6. Waste water must be treated to conform to the parameters under the Environmental Quality (Sewage and Industrial Effluents) Regulations 1979.

The Ministry decided to establish two committees to monitor the project: a Steering Committee to deal with policy issues on the

See International POPs Elimination Project, Consumer Report on the Borga Incinerator Project - A Contribution to the Public Debate on the Use of Incineration for Managing Municipal Discards in Malaysia, May 2005. See at: www.oxtoxics.org/ipepweb/library/reports/ Malaysia\%20520Borga\%20incinerator\%. 
implementation of the project; and a technical committee to monitor all technical matters. In addition to these, the Ministry has planned to set up a Monitoring Committee once construction is complete. It will be made up of members of relevant government agencies, residents' representatives and non-governmental organizations. In spite of these measures, residents were not satisfied. They ultimately went to the court, and the Court granted them an injunction. Ultimately the government decided not to go ahead with building the incinerator. It is claimed that the scraping of the Broga Incineration Project was called off not due to public opposition but to a cost factor. On 8 July 2007, Dato Seri Najib Tun Rajak, the Deputy Prime Minister then, said that the decision was not due to any protest or court action but the high capita (RM 1.5 billion) and the maintenance cost to have such an incinerator. ${ }^{84}$ This was reiterated by Dato Chang Ko Youn. ${ }^{85}$ The author is of the opinion that cost might be a factor, but the resentment of the public was also a reason. It is notable, in this context, that the letter sent to the Attorney-General's Chambers about abandoning the Broga Incineration Project did not have any reasons. ${ }^{86}$ It is also notable that Dato Shahrir Abdul Samad, the then Minister of Domestic Trade and Consumer Affairs, said that, 'it was a win-win situation. ${ }^{87}$ The author is of the opinion that incinerators and land fills have to go hand-in-hand. Incinerators, therefore, are imperatively required. There should be no public resentment if the government is ready to follow the internationally accepted standards.

The three cases, discussed above, are indicative of the fact that people in Malaysia are fast becoming environmentally conscious, and with the help of NGOs and individual environmentalists they can compel the government either to abandon unscrupulous projects or to go ahead with international standards. The government is also aware of this fact. Rather, the government is now encouraging them to come forward and participate in the decision-making, so that the interests of the environment

\footnotetext{
$84 \quad$ See The Star, 8 July 2007.

85 Dato Chang Ko Youn, Chairman of Local Government, Public Housing and Public Transport at a special seminar on $5^{\text {th }}$ December 2007, said that the project was abandoned owing to the cost. See Fathol Zaman Bukhari, “Garbage Galore,” IPOH echo, issue 41, January 2008.

$86 \quad$ See Bernama.com, 5 July 2007.

87 See at: SHAHARIR-UMNO.com; also see at: umnojb.com.my/ main.phd/i=berita \&berita=262.
} 
and general public are not compromised. Recently, the failure of the Bukit Tagar sanitary landfill operator to construct a leachate treatment facility, which was a violation of the EIA report and which was brought into notice of the DOE by the public living in the area, was considered as an illegality under section 34A of the EQ Act. Thus, the matter was referred to the Attorney-General's Chambers for legal action and necessary legal actions were taken. ${ }^{88}$ This incident prompted the government to move other dump sites that were closer to lakes and rivers. At the planning stage also public opinions are being given due consideration so that the planning becomes really sustainable.

\section{Draft Selangor Structure Plan 2002-2020}

Under section 8 of the Town and Country Planning Act 1976, Structure Plans ${ }^{89}$ are prepared. These plans are required to indicate any areas selected as 'action areas' for sustainable development or comprehensive improvement, and to suggest measures for the improvement of the physical environment, communications, management of traffic, and natural resources. Under section 9 of the Act, the Local Planning Authority has to properly notify the details of the plan and provide opportunity by other means to make representations. The authority is duty bound to consider all representations and submit them to the State Planning Committee. For facilitating the public to forward their representations, after the draft structure plan has been submitted to the State Planning Committee, the Local Planning Authority must publish a statutory notice and make arrangement about the availability of the plan for inspection for at least one month. In case the State Planning Committee is not satisfied with the public participation, it can return the plan with an instruction to make further notification and collection of public representations and to give their input in the plan. Under section 10 of the Act, the State Planning Committee can accept or reject the plan. If it

\footnotetext{
88 See The Star, 30 March 2006.

$89 \quad$ A Structure Plan generally outlines development strategies, giving indications for directions of growth, development projects and plans to meet the future needs. It covers matters like traffic and transportation, community facilities, housing, infrastructure and utilities, recreation, employment opportunities, commerce and industry and environment.
} 
considers it necessary, it can hold a hearing of the objectors and the Local Planning Authority.

A Local Plan, which has proposals for development and use of land in a particular area, must have the input of public participation based on an enquiry conducted by a three member committee appointed by the State Planning Committee. A Local Plan is not approved unless it is in conformity with the Structure Plan. With respect to Local Plans, Local Planning Authorities have more discretion.

In view of the above law, a dialogue session on the draft Selangor Structure Plan 2002-2020 between NGOs, residents associations, and representatives of the State Department of Town and Country Planning and a representative of the State Committee Chairman of Housing, Local Government, squatters and environmentalists was held. It was really a brainstorming session, where all freely expressed their views. The issues pertaining to waste generation, landfill, incinerators, and dams were discussed at length. Selangor State's Department of Town and Country Planning Director General heard everyone and gave appropriate answers to the questions directed to her. She emphasized on the 6 per cent population growth of the state and destruction of the green areas and showed the state's commitment to follow the sustainable development strategies contained in Agenda 21 and Local Agenda 21 followed by many countries. ${ }^{90}$ She concluded by saying that, "My vision for Selangor is that everybody will practice sustainable development. Decision-making must ensure development that balances social, economic and environmental concerns." ${ }^{91}$ She reiterated the state's commitment for protecting its rivers and forests.

The dialogue session indicates that local governments in Malaysia really want to implement Agenda 21 in its letter and spirit. They want to come out with a plan that satisfies all stakeholders so that the local plans are successfully carried out.

\section{Cameron Highlands District Draft Local Plan 2003-2015}

Another example is the Cameron Highlands District Draft Local Plan 2003-2015, which was claimed to have been drafted in accordance

\footnotetext{
90 See Sarah Sabaratnam, "Development, but at what cost?,” New Straits Times, 18 November 2003.

$91 \quad$ Ibid.
} 
with the National Physical Plan, Pahang Structure Plan 2002-2020, and the Cameron Highlands Structure Plan 1995-2020. This Plan was considered to be unsustainable, destructive to the environment, not in conformity with the important recommendations of the study for sustainable development of the highlands of the Peninsular Malaysia, and the policy developed by the Cabinet Committee on Highlands and Islands, which had resolved that all remaining forests of the Cameron Highlands should be gazetted as permanent forest estates. The participation of the general public was not so encouraging because they had to be benefited from the Plan. Main objections were forwarded by NGOs, especially by the WWF Regional Environmental Awareness Cameron Highlands (REACH). Some environmentalists were of the view that the Plan would be destructive to the environment, as development were to be at the slopes of 20 degrees or less and development at hilltops are against the widely accepted planning strategies. Some others opposed it because the plan was not supported by any comprehensive EIA with sufficient input of public participation. In view of these adverse but genuine objections, the Menteri Besar of Pahang, Adnan Yaakob said that he would not allow the Plan to go through, and gave his personal assurance that no more forests would be opened in Cameron Highlands as long as he was in office. ${ }^{92}$ It can be said that the decision taken by the Menteri Besar was in line with Agenda 21 and the National Physical Plan, which do not endorse clearing of forests of hills like Cameron Highlands. ${ }^{93}$ It can also be said that where local people do not realistically comment on the proposed plan, NGOs and individual environmentalists can play a constructive role and can guide the state to take necessary steps to protect the environmental and social interest.

\section{Access to Justice - Public Interest Litigations}

Access to justice is now a well-recognised human right to ensure environmental justice which can be attained through courts. A person, who has standing to sue or locus standi, ${ }^{94}$ can bring a case. A

\footnotetext{
$92 \quad$ See New Straits Times, 24 April 2005.

93 See Elizabeth John, "Environmental Plan,” New Straits Times, 31 December 2005.

94 It is a legal capacity to challenge an act or decision.
} 
representative suit can be brought only on permission of an appropriate authority. In environmental matters, a relatively large number of people can be affected, but they will remain silent sufferers if they have no capacity to bear the cost of justice. This kind of situation can be averted and justice can be brought to their doorsteps if the requirement of local standi is relaxed and representative suits do not have to pass through the Attorney-General's Chambers (hereinafter referred to as 'the AG'). In one similar situation, Lord Denning granted an injunction where an obscene programme was to be telecast and there was not enough time to take permission from the AG. ${ }^{95}$ The Canadian Supreme Court also gave the same ruling and granted an injunction order to stop aerial spraying on health grounds. ${ }^{96}$ In general, in Britain, courts have been assessing the question of standing of environmental organisations using varying considerations such as their long standing association with the subject matter, status as a consultant during the planning process, local interest, financial investments and the general importance of the subject matter. Recent cases reveal that the prayer for certiorari and mandamus are treated as public law remedies and that in such cases, a liberal approach is taken by the courts. ${ }^{97}$ Contrary to this, in the United States, courts strictly adhere to locus standi. In view of this, citizen suit provisions were incorporated when Congress found that public participation was necessary in the enforcement of environmental laws. But the courts attitude remained the same in the pretext of the need to meet the

95 Attorney General on the Relation of McWhirter v. Independent Broadcating Authority, (1973) 1 All ER 689.

$96 \quad$ Palmer v. Nova Scotia Forest Industries, (1983) 2 DLR 397. Under the Canadian State of Ontario's Environmental Bill of Rights 1993, any resident in Ontario may bring an action against anyone who has contravened or will imminently contravene any environmental law which has caused or will imminently cause significant harm to the environment, if the authorities fail to respond to his complaint of contravention or the response given is not reasonable. This provision overrides the locus standi requirement in the state.

$97 \quad$ U. Sarathchandra, "Standing to Sue in Environmental Litigation - A Comparative Analysis," at: www.geocities.com/sarathdhanusha/ paper.htm, 19. Also See David Robinson and John Dunkley (Eds.) Public Interest Perspectives in Environmental Law (London: Wiley Chancery Publishing, 1995), 45-63. 
constitutional mandate. ${ }^{98}$ The idea of public interest litigation is the invention of the American judicial system. ${ }^{99}$ In India and some other countries, ${ }^{100}$ locus standi was relaxed in environmental pollution matters where public interest was considered to be involved. This gave rise to development of jurisprudence of public interest litigations (PIL). In India, public interest litigations are too easy to be instituted; it can be just by writing a letter to the court. The court registers the case and issues summons to the relevant parties, including government departments. However, courts have taken a cautious approach in order to eliminate cases filed with an object to cause harassment or to take revenge and balancing the values of development and environment; and before deciding, they have ensured all aspects through appointing expert commissions. ${ }^{101}$ The credit, along with others, goes to some judges notably Justice P N Bhagwati, for encouraging PIL litigations, and environmentalist Mr. M C Mehta, for instituting a large number of environmental PIL cases. PIL cases have been largely helpful in ensuring environmental justice to poor and indigent people. It has also been helpful in development of environmental law in the country.

$\overline{98} \quad$ U. Sarathchandra, ibid. Also see, R. Berger, "Standing to Sue in Public Actions: is it a Constitutional Requirement?,” Yale Law Journal, vol. 78, 1969; R.B. June, “The Structure of Standing Requirements for Citizen Suits and the Scope of Congressional Power," Environmental Law, vol. 24, 1994, 38.

It emerged in the 1960's, in the socio-political context of the civil rights movement in the United States as a distinctive form of litigation. It was distinctive because its proponents actively and openly championed not just the individual rights of the plaintiff but the collective rights of the group to which the individual belonged. See B. Wadhera, Public Interest Litigation: A Handbook (New Delhi: University Law Publishing, 2003), at 37.

100 See Helen Hershkoff, "Public Interest Litigations: Selected Issues and Examples," at $<$ www.worldbank.org/publicsector/legal/publicinterest litigation.doc>; Elmeny Bray, "Locus Standi: Its Development in South African Environmental Law,” at: www.acts.or.ke/GE.chapter6.pdf.

101 See G.L. Peiris, "Public Interest Litigation in Indian Sub-Continent: Current Dimensions," International and Comparative Law Quarterly, 1991, 66-90; Arun B. Nehru, "Judicial Activism and Accountability," The Hindu Online, 28 January 1997; D.S. Sagar, "PIL to Ensure that Institutions Behave Lawfully: Public Access to environmental Justice in India,” Journal of Indian Law Institute, 2003, vol. 45:1, 62. 
Malaysian courts strictly follow locus standi. It flowed from UEM v. Lim Kit Siang ${ }^{102}$ and has been adhered to in subsequent cases. ${ }^{103}$ In Lim Kit Siang, in his remarkable dissenting judgment, Justice Abdoolcader described the majority decision as a 'retrograde step in the present stage of development of administrative law and a retreat into antiquity...' as it leads to 'closing the door to the ventilation of a genuine public grievance...'

With respect to a mandatory duty to make the EIA report available for public comments, a liberal view has been taken in Abdul Razak Ahmad v. Ketua Pengarah Kementerian Sains, Teknologi dan Alam Sekitar. ${ }^{104}$ The court ordered to make the EIA report available to the plaintiff, as it would affect him specially and the residents of Johor in general. In fact, the court recognized the locus standi of the plaintiff. In Kajing Tubek \& Ors v. Ekran Bhd. \& Ors, ${ }^{105}$ the High Court took a similar view saying that it was the right of the plaintiff to take a copy of the EIA report and, therefore, he is entitled to take it. On appeal, the Court of Appeal recognised the right to get the EIA report on demand and on payment of a required fee, provided it is allowed by law. Since in this case the Court of Appeal decided that the law of Sarawak would apply which did not provide for public participation in the EIA process, the claimant could not get it.

Representative suits in class actions, where the questions of fact and law are the same, are tenable even in countries, including Malaysia, where locus standi is strictly adhered to, are different than public interest litigations. In such cases, a suit is filed by one person or a group of

\begin{tabular}{l}
\hline $102 \quad$ [1988]2 MLJ12. \\
In Ketua Pengarah Jabatan Alam Sekitar \& Anor v. Kaing Tubek \\
and Ors. And other appeals, [1997] 3 MLJ 23. In this case Justice \\
Gopal Sri Ram ruled: “Although a litigant may have threshold locus \\
standi...he may, for substantive reason be disentitled to declaratory \\
relief.” He refused the declarations sought. See G.S. Nijar, “The Bakun \\
Dam Case: A Critique,” Malayan Law Journal [1997] 3 MLJ ccxxix; \\
Meenakshi Raman, “Environmental Law and Litigation in Malaysia: A \\
Perspective from the Ground,” paper presented at Commonwealth Law \\
Teachers Conference, Kuala Lumpur, 1998; Roger Tan, "Making class \\
action easier,” New Sunday Times, 19 February 2006. \\
[1994]2 CLJ 363. \\
[1996]2 MLJ 388.
\end{tabular}


persons from the lot who have common ground of a legal action. In the United States, for example, for a legal action there should be injury, causation and redressability. There is a prohibition about third party standing except the class action within the legal framework of the Class Action Fairness Act 2005. ${ }^{106}$ In Malaysia also the position is the same. ${ }^{107}$ In the Malaysian context, where due to poor enforcement of environmental law and some wrong administrative decisions, the conditions of the environment in general and rivers of the Klang Valley in specific are fast deteriorating, courts should relax the requirement of locus standi in environmental matters where public at large suffer, and should encourage public interest litigations. ${ }^{108}$ This requirement should also be relaxed where public participation is, in effect, denied, and where conditions appended to approved EIAs are violated, and because of that people in general are suffering. It will help in ensuring environmental justice, because the only way to provide access to justice to those who cannot manage enough resources to bear the cost of justice? This will be in conformity with the third fundamental requirement of the Aarhus Convention. The apprehension that relaxing this requirement will open the floodgate of cases, and with the result of that, regular cases will be delayed has been

106 The following cases may be referred: Jenkins v. Raymarks Industries, 782 F 2d 468 (1986); Amchem v. Windsor, 521 US 591 (1997); Ortiz v. Fiberboard Corporation, 527 US 815 (1999). Also refer to: <http:// en.wikipedia.org/wiki/class_action>

107 It is notable that prior to the Abdul Razak Ahmad case, in Jok Jou Evong v. Marabong Lumber Sdn Bhd., [1990] 2 CLJ 625 the High Court recognized plaintiffs' right to bring representative suit although they were representing only one group of the affected residents. Similarly, in Adong bin Kuwau \& Ors v. Kerajaan Negeri Johor \& Anor, [1997] 1 MLJ 418 a representative suit was entertained by the High Court and an order for payment of compensation for loss of land and other related rights was made. On appeal, the verdict of the learned judge of the High Court was upheld by the Court of Appeal. See Kerajaan Negeri Johor and Anor v. Adong bin Kuwau and Ors, [1998] 2 MLJ 158. The case is before the Federal Court. See New Straits Times, 28 April 2006.

108 According to the Malaysian Environmental Quality Report 2005, 80 rivers were found clean, 51 were determined polluted and 15 rivers were found highly polluted. Among the pollutants, 43 were highly polluted by Amonical Nitrogen and 34 were highly polluted by suspended solids. 
proved to be false in India and elsewhere. In fact, representative suits have helped reduce multiplicity of cases. It is also notable that judges are careful and disallow phantom cases based on surmises or personal grudges. Other than imparting justice to aggrieved parties, PIL cases have been helpful in proper enforcement of the law, especially environmental law and development of environmental jurisprudence. India is one of the best examples of this. The other way to allow public interest litigation is to have appropriate legislation to facilitate it. The author is of the opinion that the first choice is better because without special interest of courts, the object of such legislation cannot be achieved. It is appropriate to say that without judicial activism, public interest litigations cannot yield the desired result.

\section{CONCLUSION}

The three cardinal points of participatory justice - environmental information, public participation, and access to justice - have succinctly been enshrined in principle 10 of the Rio Declaration and the Aarhus Convention. They are rightly being considered as sine qua non for serving various environment and social interests. But public participation and access to justice can be effective only when people are well informed about deleterious effects on the environment of developmental activities and are encouraged by the DOE, Planning Department and NGOs for the same. It can very well be understood in an EIA process. Proper enforcement of an EIA regime in the interest of the state, proponent and the public cannot be achieved without effective public participation, because public participation might highlight certain deleterious effects which were not anticipated by the first two interest groups, the state and the proponent. Thus, with the appropriate input of public participation, a proposed project can be more genuine, viable, and acceptable to the people. In no case, environment should be compromised for development. Rather, we should strike a meaningful balance, based on a genuine EIA.

Public encouragement by relevant government departments becomes more important in developing countries like Malaysia, where in most of the cases, affected people are poor villagers, squatters or forest inhabitants. In these countries, the role of NGOs has been commendable. It is therefore suggested that the Malaysian DOE and other relevant departments should increase the number of trained personnel at the 
department, and should encourage people and NGOs to come forward and offer their suggestions on the draft EIA and SIA reports. The specific cases discussed above reveal that the Malaysian public and NGOs have actively participated in finalising some development plans. This is because they were encouraged to attend joint meetings and to make fruitful comments without any inhibition or fear. This should be practiced in finalising EIAs of all mega projects also.

Where law is not properly enforced, the ambience becomes momentously harmful and people at large suffer, public interest litigations can bring justice to them. But this is not possible in some countries, including Malaysia, where locus standi is strictly adhered to by the courts. It is therefore suggested that like India and the Philippines, in these countries also courts should relax this requirement. If it is not done, NGOs should come forward and help poor sufferers - like the Asian Rare Earth case of Malaysia - in bringing cases for ensuring the right to a healthful environment of affected people.

Courts can play an enormous role in enhancing public participation in planning and developmental activities. This will be possible only when they give wide application to the provisions pertaining to public participation in the Environmental Quality Act 1974 and the Town and Country Planning Act 1976. 